\title{
Karakteristik Kemiskinan Di Provinsi Papua Barat Setelah Otonomi Khusus
}

\author{
Sarce Babra Awom ${ }^{1}$ \\ ${ }^{1}$ Dosen Jurusan Ekonomi Pembangunan, Universitas Papua
}

Permalink/DOI: https://doi.org/10.36883/jfres.v4i2.62

Received: September 2021; Accepted: September 2021; Published: September 2021

\begin{abstract}
Abstrak
Penelitian ini bertujuan untuk menganalisis bagaimana karakterisitik tingkat kemiskinan di Provinsi Papua Baratdan apakah belanja dana otonomi khusus $\left(\left(\mathrm{X}_{1}\right)\right.$ berpengaruh terhadap fluktuasi tingkat kemiskinan di provinsi Papua Baratsejak tahun 2009-2019, setelah otonomi khuus, data sekunder secara time series dianalisis, menggunakan metode yang kuantitatif dan deskriptif, model regresi sederhana. Dari hasil analisis regresi sederhana dengan bantuan SPSS. Hasil uji secara simultan maupun parsial, nilai signifikasi $(0,000)$ lebih kecil dari derajat kebebasan 0,05 (5\%), sehingga disimpulkan bahwa belanja dana otsus mempengaruhi fluktuasi tingkat kemiskinan, diprovinsi papua Barat, namun tidak semuanya, karena $\mathrm{R}^{2}$. Hanya $67 \%$ sedang $33 \%$ dipengaruhi oleh andanya program bantuan dana desa, namun tidak terukur dalam penelitian ini.
\end{abstract}

Kata kunci: karateristik kemiskinan, otonomi khusus, belanja pemerintah

\begin{abstract}
This study aims to analyze spending and the characteristics of the poverty level in the province of West Papua and whether the special autonomy fund spending has an effect on fluctuations in levels of poverty in the province of West Papua from 2009-2019 after special autonomy. The method used in this research is quantitative and descriptive. The analysis technique uses secondary data and uses simple regression analysis. From the result of simple regression analysis with the help of the application program, the test results both simultaneously and partially show that the significance value $(0,000)$ is smaller than the sensitivity degree value of $0,05(5 \%)$ so it can be concluded that in a time series, spending on special autonomy funds has an effect on significant fluctuations in poverty levels in the province of West Papua, but not all of them because $\mathrm{R}^{2}$ (R Square) only $67 \%$ were $33 \%$ influenced by the village fund assistance program, but not measured in this study.
\end{abstract}

Keywords: characteristics of poverty, special autonomy, government expenditure

How to Cite: Awom, S.B., (2021). Karakteristik Kemiskinan Di Provinsi Papua BaratSetelah Otonomi Khusus. JFRES: Journal of Fiscal and Regional Economy Studies, 4(2), 27 - 34, doi: https://doi.org/10.36883/jfres.v4i2.62.

Corresponding author:
E-mail: s.awom@gmail.com 


\section{PENDAHULUAN}

Kemiskinan merupakan permasalahan yang multidimensional.dan kompleks, berbagai Upaya pengentasan guna pengurangan kemiskinan terus $\mathrm{s}$ dilakukan secara komperhensif, mencakup seluruh aspek hidup dan dilaksanakan secara terpadu. Kemiskinan terjadi karena kemampuan masyarakat sebagai pelaku ekonomi tidak sama, sehingga ada sebagian masyarakat yang tidak mampu ikut serta dalam proses pembangunan atau menikmati hasil pembangunan (Soegijoko, 2001). Kemiskinan juga merupakan halmasalah klasik yang belum tuntas terselesaikan terutama di Negara berkembang, artinya bahwa kemiskinan menjadi masalah yang harus dihadapi dan perhatian di setiap Negara. Persoalan kemiskinan merupakan salah satu permasalahan pokok yang dihadapi bangsa Indonesia sejak dahulu hingga sekarang. Berbagai perencanaan, kebijakan serta program pembangunan yang telah danakan dilaksanakan pada intinya adalah mengurangi jumlah penduduk miskin

Kemiskinan merupakan salah satu masalah mendasar yang menjadi pusat perhatian pemerintah di negara manapun. Di hampir semua Negara berkembang, standar hidup dari sebagaian besar penduduknya cenderung sangat rendah, jika dibandingkan dengan standar hidup orang-orang di negara kaya, atau dengan golongan elit di negara mereka sendiri. Standar hidup yang rendah tersebut terwujud salah satunya dalam bentuk tingkat pendapatan yang sangat minimum atau kemiskinan (Todaro,2004).

Undang-Undang Nomor 21 Tahun 2001 tentang Otonomi Khusus Bagi Provinsi Papua sebagaimana telah diubah dengan UndangssUndang Nomor 35 tahun 2008 tentang Penetapan Peraturan Pemerintah Pengganti Undang Undang Nomor 1 Tahun 2008 tentang Perubahan Atas Undang Undang Nomor 21 Tahun 2001 tentang Otonomi Khusus Bagi Provinsi Papua, bahwa Provinsi Papua Baratsebagai pemekaran dari Provinsi Induk Papua.

Peran Otonomi Khusus di Papua Barat, bertujuan untuk mempercepat peningkatkan kesejahteraan masyarakat orang asli papua, sehingga mempercepat penurunan angka kemiskinan dan mengejar ketertinggalan pembangunan di Provinsi Papua dan Papua Baratdi bandingkan dengan Provinsi lain di Indonesia.

Manfaat Undang-undang Otonomi khusus tahun 2001 ini membuka ruang dan kesempatan bagi Pemerintah daerah untuk menjabarkan dalam peraturan pelakasanan berupa Perdasi (peraturan daerah provinsi) dan perdasus (peraturan daerah khusus) yang menetapkan hakhak dasar orang asli papua dimana pembangunan harus mengacuh pada hak-hak dasar, Selain adanya Dana Otonomi Khusus yang diberikan secara langsung kepada Provinsi Papua dan Papua Barat, terdapat dana tambahan yang ditujukan untuk pembiayaan pembangunan infrastruktur atau secara umum disebut sebagai Dana Tambahan Infrastruktur (DTI).

Penetapan Anggaran di tentukan oleh Pemerintah Pusat bersama dewan perwakilan rakyat pusat berdasarkan usulan Provinsi, Papua Bara tsetiap tahun anggaran. Dan dana terkait otonomi khusus yang tidak diperoleh provinsi lain ini telah memasuki usia 19 tahun yang artinya hampir mendekati titik akhir masa berlakunya Dana Otonomi Khusus Papua dan Papua Barat. Berdasarkan latar belakang diatas maka, rumusan masalah dalam penelitian ini adalah: bagaimana karateristik tingkat kemiskinan di Provinsi Papua BaratSesudah Otonomi khusus? Dan Apakan belanja dana otonomi khusus Berpengaruh terhadap fluktuasi tingkat kemiskinan di Provinsi Papua Baratsetelah Otonomi khusus? Tujuan dan Manfaat dalam penelitian ini adalah: Untuk mengetahui karakteristik tingkat kemiskinan di Provinsi Papua Baratdan pengaruh belanja dana otonomi khusus terhadap fluktuasi tingkat kemiskinan di Provinsi Papua Baratsetelah Otonomi Khusus.

Kemiskinan merupakan keterbatasan seseorang, keluarga, komunitas atau bahkan negara atas apa yang disandang sehingga yang menyebabkan ketidak nyamanan memenuhi kebutuhan, terancamnya penegakan hukum dan keadilan serta hilangnya generasi dan suramnya masa depan bangsa dan negara. Dalam segala bidang sehingga measyarakatnya menjadi kaum tersingkir karena tidak dapat menyamakan 
kondisinya dengan kondisi masyarakat sekitarnya (Arsyad, 1999) menjelaskan Kemiskinan multi dimensional, terjadi karena kebutuhan manusia itu bermacam-macam, maka kemiskinan pun memiliki banyak aspek primer yang berupa miskin akan aset, organisasi sosial politik, pengetahuan, dan keterampilan serta aspek sekunder yang berupa miskin akan jaringan sosial, sumber-sumber keuangan, dan informasi. Dimensi-dimensi kemiskinan tersebut termanifestasikan dalam bentuk kekurangan gizi, air, perumahan yang sehat, perawatan kesehatan yang kurang baik, dan tingkat pendidikan yang rendah. Selain itu, dimensidimensi kemiskinan saling berkaitan baik secara langsung maupun tidak langsung.

Ukuran kemiskinan menurut Nurkse (dalam Arsyad, 1999), secara sederhana dan yang umum digunakan dapat dibedakan menjadi dua pengertian: Kemiskinan Absolut terjadi ketika pendapatan seseorang berada di bawah garis kemiskinan mampu untuk memenuhi kebutuhan dasar hidupnya. dipengaruhi oleh adat kebiasaan saja, tetapi juga iklim, tingkat kemajuan suatu negara, dan faktor-faktor ekonomi lainnya. Walaupun demikian, untuk dapat hidup layak, seseorang membutuhkan barang-barang dan jasa untuk memenuhi kebutuhan fisik dan sosialnya. Dan Kemiskinan Relatif terjadi ketika Seseorang termasuk golongan miskin relatif apabila telah dapat memenuhi kebutuhan dasar hidupnya, tetapi masih jauh lebih rendah dibandingkan dengan keadaan masyarakat sekitarnya. Berdasarkan konsep ini, garis kemiskinan akan mengalami perubahan bila tingkat hidup masyarakat berubah sehingga konsep kemiskinan ini bersifat dinamis atau akan selalu ada. Oleh karena itu, kemiskinan dapat dari aspek ketimpangan sosial yang berarti semakin besar ketimpangan antara tingkat penghidupan golongan atas dan golongan bawah, maka akan semakin besar pula jumlah penduduk yang dapat dikategorikan selalu miskin.

World Bank membuat garis kemiskinan absolut US\$ 1 dan US\$ 2 PPP (Purchasing Power Parity/ paritas daya beli) per hari. United Nations Development Programme (UNDP) dalam laporannya pada Human Developnment Report (HDP) 1997, memperkenalkan ukuran kemiskinan dengan menggunakan Indeks Kemiskinan Manusia (Human Poverty Index-
HPI) yang diukur dalam 3 hal utama (three key deprivations), yaitu kehidupan (lebih dari 30 persen penduduk negara-negara yang paling miskin cenderung hidup kurang dari 40 tahun), pendidikan dasar diukur oleh persentase penduduk dewasa yang buta huruf, serta keseluruhan ketetapan ekonomi (economic provisioning) yang diukur dengan melihat persentase penduduk yang tidak memiliki akses terhadap pelayanan kesehatan dan air bersih ditambah persentase anak-anak dibawah usia 5 tahun yang kekurangan berat badan. Apabila angka HPI semakin rendah maka menunjukkan bahwa tingkat kesejahteraan semakin baik, dan turut pula sebaliknya (Todaro, 2006).

Badan Pusat Statistik (BPS) 2020 menjelaskan bahwa Provinsi Papua Baratmengalami penurunan presentase penduduk miskin dari tahun 2009 berjumlah 31.43 persen, pada tahun 2014 berjumlah 26.26 persen dan pada tahun 2019 berjumlah 22.17 persen. Dapat dilihat dari grafik bahwa ada 6 kabupaten dengan jumlah angka kemiskinan yang tinggi yaitu kabupaten teluk bintuni berjumlah 39.48 persen, pada kabupaten teluk wondama berjumlah 39.02 persen, pada kabupaten tambrauw berjumlah 34.85 persen, pada kabupaten sorong berjumlah 33.00 persen, pada kabupaten maybrat berjumlah 32.37 persen, dan pada kabupaten fak-fak berjumlah 28.88 persen Walaupun menglami penurunan provinsi Papua Baratmasih dalam kategori miskin kedua setalah provinsi papua karena masih terdapat beberapa kabupaten dengan angka kemiskinan yang relatif tinggi.

\section{METODE PENELITIAN}

Metode analisis yang digunakan secara kuantitatif dan deskriptif , di hitung menggunakan metode statistik parametric dengan pemodelan regresi sederhana jumlah tahun observasi dari 2009-2019 (Time Series), dengan variabel Independen (Y) adalah Tingkat Kemiskinan dan Variabel Dependen $\left(\mathrm{X}_{1}\right)$ adalah belanja dan otonomi khusus. Persamaan yang digunakan adalah:

$\mathrm{Y}=\alpha+\beta_{1} \mathrm{X}_{1}+\mathrm{e}$

Dalam proses pengolahan data akan terlebih dahuluh dilakukan pegujian data; diantaranya Pengujian Asumsi Klasik (Uji Normalitas dan Autokorelasi) tujuan Uji 
asumsi klasik adalah agar persyaratan statistik yang harus dipenuhi pada analisis regresi linear yang berbasis Ordinary Least Square (OLS). Jadi, analisis regresi yang tidak berdasarkan OLS tidak memerlukan persyaratan asumsi klasik. Dan pengujian Statistik Uji Hipotesis Secara Simultan (Uji f) Pengujian dilakukan dengan menggunakan tingkat signifikansi 0,05 $(\alpha=5 \%)$. Uji parsial (Uji t) kriteria atau penolakan hipotesis sebagai berikut:

a. Jika nilai signifikan $>0,05$ maka hipotesis nol diterima (koefisien regresi tidak signifikan). Hal ini berarti bahwa secara parsial variabel independen tersebut tidak mempunyai pengaruh yang signifikan terhadap variabel dependen.

b. Jika nilai signifikan $<0,05$ maka hipotesis nol ditolak (koefisien regresi signifikan). Hal ini berarti secara parsial variabel independen tersebut mempunyai pengaruh yang signifikan terhadap variabel dependen.

\section{HASIL PENELITIAN}

Tujuan penelitian ini adalah untuk mengukur pengaruh (X1) Belanja Otonomi Khusus terhadap (Y) Tingkat Kemiskinan di Provinsi
Papua Barat, tahun 2009-2019 dilakukan beberapa penujian maka didapatkan hasil pengujian seperti pada gambar 1 .

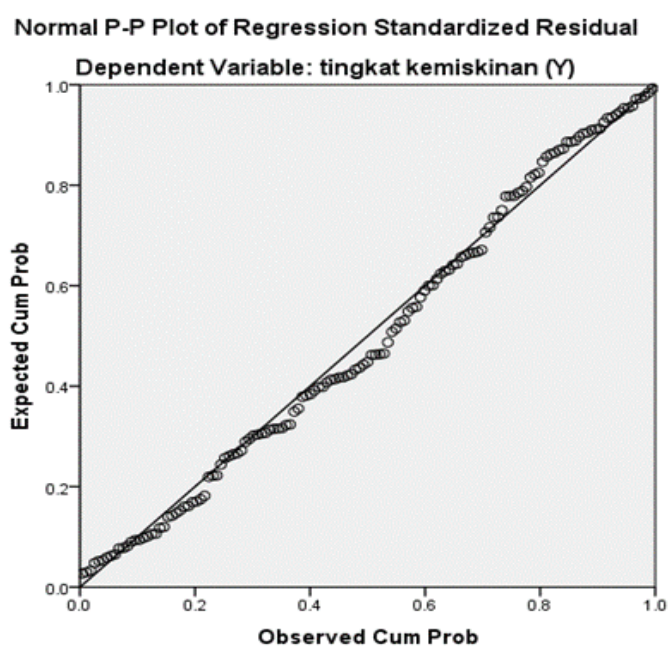

Sumber: Data Output SPSS Diolah, 2021

Gambar 1. Uji Normalitas Plot

Tujuan dilakukan pengujian autokorelasi adalah untuk mengetahui adakah korelasi variabel yang ada dalam model regresi. Untuk melihat terjadi atau tidak terjadinya autokorelasi dalam regresi ini maka digunakan dasar pengambilan keputusan dengan melihat nilai durbin-watson dengan asumsi mendekati angka 1 .

Tabel 1. Uji Autokorelasi

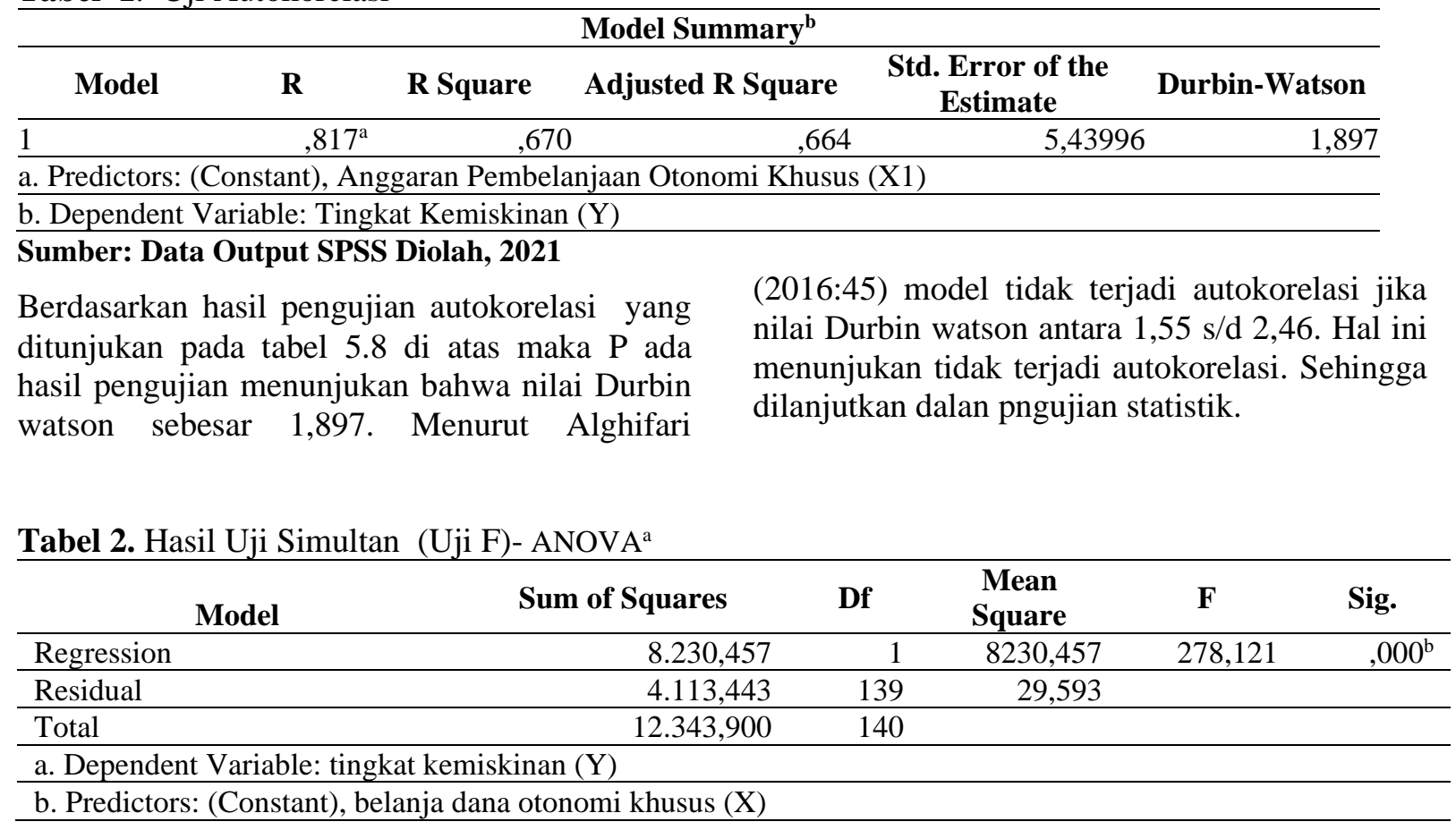


Sumber: Data Output SPSS Diolah, 2021

Tabel 3. Hasil Uji Parsial (Uji T)

\begin{tabular}{|c|c|c|c|c|c|c|}
\hline \multicolumn{7}{|c|}{ Coefficients $^{\mathrm{a}}$} \\
\hline & \multirow{2}{*}{ Model } & \multicolumn{2}{|c|}{$\begin{array}{c}\text { Unstandardized } \\
\text { Coefficients }\end{array}$} & \multirow{2}{*}{$\begin{array}{c}\begin{array}{c}\text { Standardized } \\
\text { Coefficients }\end{array} \\
\text { Beta } \\
\end{array}$} & \multirow{2}{*}{$\mathbf{t}$} & \multirow{2}{*}{ Sig. } \\
\hline & & B & $\begin{array}{c}\text { Std. } \\
\text { Error }\end{array}$ & & & \\
\hline & (Constant) & 157,747 & 7,586 & & 20,794 &, 000 \\
\hline & Belanja Dana Otonomi Khusus (X) & $-1,398$ & 084 &,- 817 & $-16,677$ & 000 \\
\hline
\end{tabular}

Sumber: Data Output SPSS Diolah, 2021

Untuk melihat pengaruh atau tidak pengruhnya pengujian simultan maka dasar pengambilan keputusan yang di gunakan adalah dengan melihat nilai signifikansi dengan nilai probabilitas jika nilai sig < probabilitas maka ada pengaruh yang terjadi secara simultan dari variabel $\left(\mathrm{X}_{1}\right)$ terhadap Y. Berdasarkan hasil pengujian uji $F$ pada tabel 2 yang dilakukan dengan bantuan program SPSS, diperoleh nilai signifikansi sebesar 0,00 , jadi nilai signifikansi ini lebih kecil daripada nilai $\alpha$ yaitu 0,05 . Karena nilai (sig $<\alpha=0,00<0,05$ ) maka $\mathrm{H}_{0}$ diterima, signifikansi yang berarti bahwa variable $\left(X_{1}\right)$ belajanja dana otonomi khusus berpengaruh secara simultan terhadap variabel (Y) tingkat kemiskinan di Papua Barat. Dan hasil output Uji Parsial (Uji t) di atas, variabel $X_{1}$, diperoleh nilai signifikansi sebesar 0,00 . Jadi, nilai signifikansi ini lebih kecil dari pada nilai $\alpha$ yaitu 0,05 . nilai (sig $<\alpha=0,000<$ 0,05 ) nilai t hitung > t table $-16,677>2,10982$ sehingga disimpulkan variabel $\left(\mathrm{X}_{1}\right)$ belanja dana otonomi khusus berpengaruh signifikan secara parsial terhadap variabel (Y) tingkat kemiskinan di Papua Barat.

Persentase kemampuan variabel belanja dana otonomi khusus $(\mathrm{X})$ terhadap variabel tingkat kemiskinan $(\mathrm{Y})$ yang di tunjukan pada tabel 5.7 di atas pada kolom $R$ Square adalah sebesar 0,670 atau sebesar $(67 \%)$ dijelaskan bahwa variabel (X1) belanja dana otonomi khusus cukup mampu menjelaskan variabel (Y) pendapatan tingkat kemisikinan $67,0 \%$ dan sebesar 33\% di pengaruhi variabel lain yang tidak ukur kedalam penelitian ini misalnya Pengeluaran Rumah Tangga Masyarakat (Konsumsi) dan Distribusi Pendapatan.
Berdasarkan tabel 3 dapat dibuat persamaan regresi sebagai berikut :

$\mathrm{Y}=157,747+-1,398 \mathrm{X}_{\mathrm{i}}+\mathrm{e}$

Nilai konstanta sebesar 157,747 sedangkan nilai koefisien regresi untuk belanja dana otonomi khusus (X) sebesar -1,398. Hal ini menjelaskan bahwa Pada saat Variabel (varibel X) belanja dana otonomi khusus berpengaruh signifikan terhadap variabel $\mathrm{Y}$ fluktuasi tingkat kemiskinan tetap konstan sebesar 157,747.

Nilai koefisien regresi dari belanja dana otonomi khusus $(\mathrm{X})=0$ maka nilai variabel $\mathrm{Y}=157,747$ (konstan), dan jika variabel $\mathrm{X}$ bertambah sebesar 1\% maka variabel $\mathrm{Y}=, 398$ yang menjelaskan bahwa setiap kenaikan satu persen satuan variabel belanja dana otonomi khusus (X) akan menurunkan angka variabel tingkat kemiskinan (Y) sebesar -1,398 dengan asumsi bahwa faktor lain tetap.

Adanya pengaruh belanja otonomi khusus terhadap kemiskinan di papua barat, berdasarkan hasil regresi linear sederhana menunjukan bahwa $\mathrm{T}$ hitung $-16,677>\mathrm{T}$ table 2,10982 sehingga $\mathrm{H}_{0}$ diterima berarti bahwa nilai konstanta sebesar 157,747 sedangkan untuk belanja dana otonomi khusus sebesar $-1,398$ berarti setiap kenaikan 1 persen belanja otonomi khusus bisa menekan anggka kemiskinan di Provinsi Papua Barat.

Penelitian ini sama dengan penelitian Dwiatmojo (2017), karena sama-sama meneliti tentang kemiskinan namun yang membedahkan dengan penelitian yang ini tentang otonomi khusus variabel yang digunakan yaitu belanja otonomi khusus sedangkan yang digunakan di dalam penelitian Dwiatmojo yaitu 5 variabel (X) adalah IPM, PDRB, Inflasi, Jumlah Penduduk dan 
pengganguran, dan 1 variabel $(\mathrm{Y})$ yaitu Tingkat Kemiskinan. Namun pada hasil penelitian terdahulu hanya 1 variabel yang tidak signifikan. Dalam penelitian yang saya gunakan juga signifikan antara belanja otonomi khusus terhadap tingkat kemiskinan di provinsi Papua Barat pada tahun (2009-2019).

Disaat penerimaan dana otonomi khusus sejak pada tahun 2002-2008 terus mengalami peningkatan dari tahun ke tahun namun dengan angka kemiskinan masih terus meningkat di beberapa Kabupaten-Kabupaten yang masih bergabung dengan Provinsi Papua. Namun ada beberapa kabupaten baru yang penerimaan dana otonomi khusus belum ada sehingga tingkat kemiskinan masih terus meningkat di kabupaten tersebut oleh sebab itu pemekaran Provinsi Papua Barat dan 9 kabupaten yang bergabung dengan provinsi papua dikembalikan dan menerima dana otonomi khusus sejak tahun 2009-sekarang. sudah dan telah dijalankan pada Provinsi Papua Barat. Penerimaan dan otonomi khusus di Provinsi Papua Baratpada tahun 20092019 mengalami fluktuasi di bebarapa tahun tersebut namu pada tingkat kemiskinan di Papua Baratmengalami penurunan walaupun relative kecil dengan demikian pemekaran Provinsi Papua Barat, yang memiliki 12 Kabupaten 1 Kota yang masing-masing kabupaten menerima dana otonomi khusus tersebut dan pada data membuktikan bahwa angka kemiskinan di Papua Baratmengalami penurunan disetiap tahun.

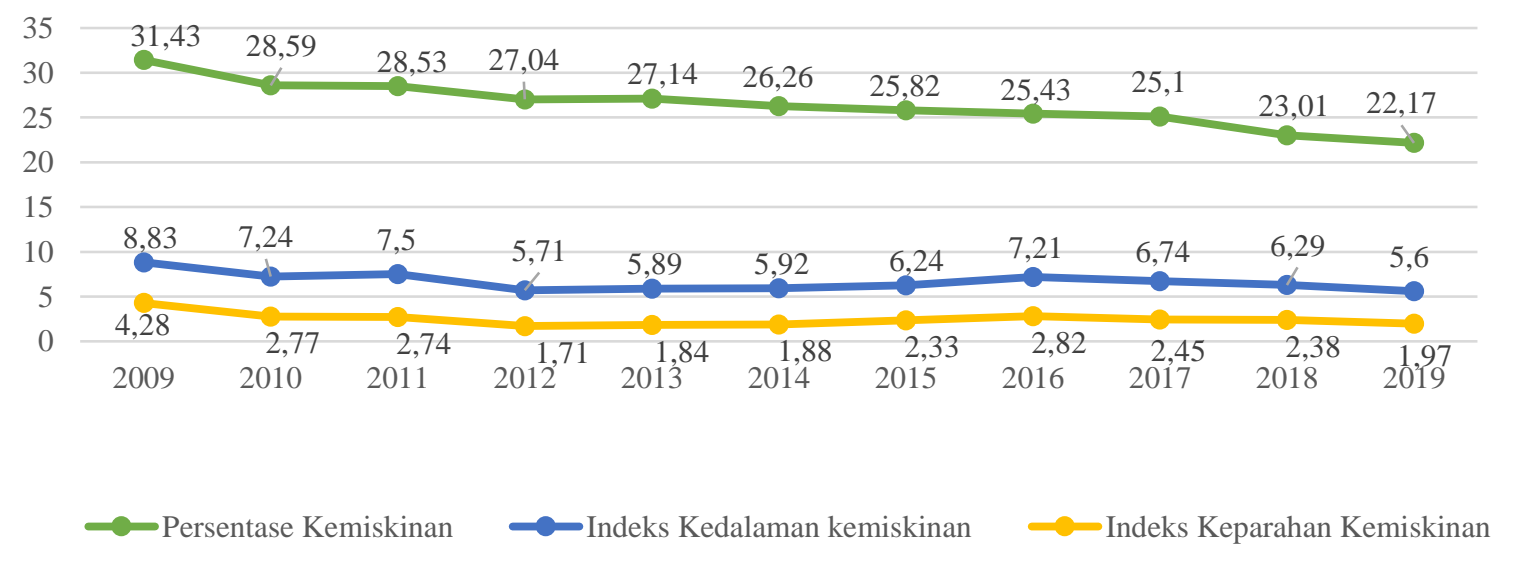

Gambar 2. Komposisi Tingkat Kemiskinan, Indeks Kedalaman Kemiskinan dan Tingkat Keparahan Kemiskinan di Provinsi Papua Barat, Tahun 2009-2019

Seiring dengan meningkatnya jumlah penduduk Papua Baratpada tahun. Sejak tahun 2019 jumlah penduduk Papua Barat berjumlah 9,596,17 yang lebih meningkat dari tahun 2018 berjumlah 9.37458.00 dan terus meningkat pada tahun 2020 berjumlah 9,818.22.00 sangat berpengaruh terhadap kondisi sosial ekonomi masyarakat di provinsi Papua Barat sejak adanya pengembangan daerah dan kampung, indeks kedalaman kemiskinan di Provinsi Papua Baratmengalami fluktuasi namun pada tahun 2009 berjumlah 8.83 persen, pada tahun 2014 mengalami penurunan berjumlah 5.92 persen dan pada tahun 2019 berjumlah 5.6 persen. Pada grafik di atas dapat dilihat bahwa indeks kedalaman kemiskinan teringgi berada di kabupaten teluk bintuni berjumlah 12.33 persen, pada kabupaten teluk wondama berjumlah 10.40 persen, pada kabupaten sorong berjumlah 86.20 persen dan pada kabupaten manokwari berjumlah 77.50 persen. Kondisi ini termasuk dalam kategori miskin karena mengalami penurunan dan masih dibawah garis kemiskinan yang relative tinggi pada beberapa kabupaten. Pada indeks keparahan kemiskinan di Provinsi Papua Baratmengalami fluktuasi namun pada tahun 2009 berjumlah 4.28 persen dan pada tahun 2019 mengalami penurunan berjumlah 1.97 persen. 
Menurut Sukirno (2004), pendapatan perkapita adalah pendapatan rata-rata penduduk suatu negara atau daerah pada suatu periode tertentu yang biasanya satu tahun. Pendapatan perkapita dihitung berdasarkan pendapatan daerah dibagi dengan jumlah penduduk. Pendapatan perkapita sering digunakan sebagai ukuran kemakmuran dan tingkat pembangunan suatu negara maupun daerah indonesia merupakan salah satu negara berkembang yang menduduki peringkat ke 4 dunia setalah Thailand, rusia dan india. Salah satu tolak ukur keberhasilan pembangunan suatu negara adalah rendah nya angka kemiskinan. Dengan jumlah penduduk yang besar, indonesia tidak dapat terhindar dari masalah kemiskinan tersebut. Hal ini dibuktikan dengan jumlah penduduk miskin yang mencapai 25,67juta/jiwa pada tahun 2019 (Badan Pusat Statistik, 2019). Data kemiskinan Papua Barat terus mengalami penurunan dari tahun ke tahun walaupun peneriman dana otonomi khusus yang mengalami fluktuasi, bisa menekan angka kemiskinan walaupun relatif kecil.

Tingkat kemiskinan Papua Barat pada tahun 2009 sebesar 31.43. Selanjutnya, pada tahun 2010 besar pengeluaran untuk dana Otonomi Khusus sebesar 96.85 dan angka kemiskinan sebesar 31.43 persen, dengan 9 urusan wajib dan 5 urusan pilihan dengan realasisi anggaran sebesar 99 persen pada urusan wajib pekerjaan umum, perumahan, perhubungan, koperasi dan atau usaha menengah dan pemberdayaan masyarakat desa.

Berdasarkan besarnya pengeluaran untuk setiap urusan wajib dan urusan pilihan, diketahui angka kemiskinan Papua Barat pada tahun 2010 turun sebesar 3 persen sehingga angka kemiskinan pada tahun 2010 sebesar 28,59 persen. Pada tahun 2011 besar realisasi anggaran otonomi khusus sebesar 90.00 persen dengan pengeluaran terbesar pada urusan wajib perumahan, koperasi dan usaha kecil menengah dan urusan pilihan perdagangan sebesar 99 persen. Dilihat dari data diatas besar pengeluaran dibandingkan dengan angka kemiskinan pada tahun 2011 hanya menurunkan angka kemiskinan sebesar 0.6 persen sehingga pada tahun 2011 angka kemiskinan sebesar 28.53 persen.

Pengeluaran otonomi khusus pada tahun 2012 hanya menurunkan angka kemiskinan sebesar 27.04 persen atau hanya menurunkan 1 persen dari tahun 2011. pada tahun 2013 dana otonomi khusus menurunkan angka kemiskinan 27.14 persen. pada tahun 2014 angka kemiskinan turun sebesar 1 persen dengan besar dana otonomi khusus 81.00 persen sehingga jumlah angka kemiskinan pada tahun 2014 sebesar 26.26 persen. pada tahun 2015 besar pengeluaran dana otonomi khusus sebesar 69.91 dengan pengeluaran terbesar pada urusan pilihan perdagangan sebesar 99.89 persen dengan demikian berdasarkan data biro otsus Papua Baratkemiskinan di tahun 2015 turun sebesar 1 persen sehingga angka kemiskinan Papua Baratsebesar 25,82 persen. pada tahun 2016 realisasi anggaran otonomi khusus sebesar 72.36 dengan angka kemiskinan sebesar 25.43 persen, atau turun 0,39 persen.

Angka kemiskinan ini masih tetap pada tahun 2017 dan pada tahun 2018. Angka kemiskinan turun sebesar 2 persen sehingga pada tahun 2018. Sedangkan, angka kemiskinan Papua Baratsebesar 23.1 persen pada tahun 2019 pengeluaran dana otonomi khusus turun yaitu sebesar 80.08 persen yang menurunkan angka kemiskinan sebesar 1 persen sehingga tingkat kemiskinan pada tahun 2019 sebesar 22,17 persen.

Dengan demikian, dana pengeluaran Otonomi Khusus Papua Baratdengan 9 urusan wajib dan 5 urusan pilihan dari tahun 2009-2019 mampu menekan angka kemiskinan sebesar kurang lebih 1-2 persen dan hanya satu kali naik sebesar 3 persen pada tahun 2010. Hal ini menjelaskan bahwa dana Otonomi Khusus belum sepenuhnya menjalankan amanat undang-undang dengan tujuan menekan angka kemiskinan hal ini di buktikan dengan tujuan menekan angka kemiskinan hal ini juga di buktikan dari data dan realita yang terjadi selama 11 tahun terkahir dari tahun 2009-2019.

\section{KESIMPULAN}

Berdasarkan hasil analisis data secara time series dari tahun 2009-2019, maka dapat diberikan kesimpulan bahwa belanja dana otonomi khusus dianalisis baik secara simultan dan juga secara parsial, variabel $\mathrm{X}_{1}$ berpengaruh signifikan terhadap fluktuasi tingkat kemiskinan di Provinsi Papua Barat. Karena nilai signifikan $0,000<0,05$ (level of signficant 5\%) dan besar nilai $R^{2}$ (R Square) menjelaskan bahwa variabel 
X kemampuan belanja dana otonomi khusus menjelaskan tingkat kemiskinan di Provinsi Papua Baratpada tahun 2009-2019 sebesar 6,70 persen. Artinya, belanja dana otonomi khusus cukup mampu menekan angka kemiskinan karena jumlah penduduk miskin turun sedang indeks kedalaman dan indeks keparahan tetap (stag). Maka pemerintah sebagai pengelola, pengendali, pemanfaatan anggaran belanja dana otonomi khusus, perlu melakukan kontrol dan evaluasi secara rutin, upaya pemerintah dalam mengentaskan kemiskinan di Indonesia, berupa adalanya kebijakan dana desa dan provinsi Papua Barat terlibat langsung dalam pengelolaan dana desa.

\section{DAFTAR PUSTAKA}

Alghifari, 2016. Mengukur Kualitas Layanan. Cetakan Kesatu. Jakarta, BPFE.

Arsyad, Lincolin, 1999. Pengantar Perencanaan Dan Pembangunan Ekonomi Daerah. Yogyakarta. BPFE.

Arsyad, Lincolin. 1999. Ekonomi Pembangunan. Edisi Keempat. Yogyakarta. Penerbit BP STIE YKPN.
BPS Papua Barat (BPS), 2020. Data Dan Informasi Kemiskinan Provinsi Papua Barat, 2020.

Dwiatmojo, W. F. 2017. Analisis Tingkat Kemiskinan Di Provinsi Jawa Tengah Tahun 2011-2015. 1-13.

Soegijoko, Budhy T. et al. 2001. "Pengelolaan Perkotaan dalam Menghadapi Tantangan Pembangunan Perkotaan". Prosiding-Forum Manajemen Perkotaan, Bandung.

Sukirno, S. 2004. Makro Ekonomi Teori Pengantar. Jakarta. PT. Raja Grafindo.

Todaro, Michael P. 2004. Pembangunan Ekonomi Di Dunia Ketiga. Edisi delapan, Jakarta. Erlangga.

Todaro, Michael P., dan Smith, Stephen, 2006. Pembangunan Ekonomi. Edisi Keenam, Jakarta. Erlangga. 